\title{
Revisitando a "Teoria do Crescimento da Firma" sob as perspectivas de Penrose e Kirzner: conteúdos e divergências
}

\author{
Lucas Casonato \\ Armando Dalla Costa²
}

\begin{abstract}
Resumo: Este artigo propõe uma releitura metodológica original das principais conclusões do livro "Teoria do Crescimento da Firma", de Edith Penrose, sob a ótica da Escola Austríaca, com ênfase nas ideias de Israel Kirzner. Apresenta uma introdução da Teoria Neoclássica da firma, e discute como ela é entendida e criticada por Penrose e Kirzner. Com isso, faz uma revisão da teoria proposta no livro de Penrose, analisando como suas conclusões são consequências necessariamente dependentes dos caminhos metodológicos percorridos pela autora, ao antropomorfizar na firma as ações empresariais que são de caráter exclusivo do homo agens. Constata que Penrose, ao seguir uma metodologia não muito bem definida, e que nem mesmo é expressa por ela, ignora o subjetivismo e o individualismo defendidos pela Escola Austríaca, acabando por propor não mais que uma leitura unilateral da firma, em uma perspectiva gerencial que olha as empresas de dentro para fora, na busca de oportunidades de lucro, mas que incorre no erro de deixar de lado a característica essencial do processo de mercado, a competição empresarial.
\end{abstract}

Palavras-chave: Teoria da firma. Metodologia. Penrose. Kirzner.

Classificação JEL: B53, D21, B41.

\section{Revisiting "The Theory of the Growth of the Firm" from the perspective of Penrose and Kirzner: contents and divergences}

\begin{abstract}
This article proposes an original methodological re-reading of the main conclusions of the book "Theory of Firm Growth", by Edith Penrose, from the perspective of the Austrian School, with an emphasis on the ideas of Israel Kirzner. It
\end{abstract}

1 Doutorando pelo Programa de Pós-Graduação em Desenvolvimento Econômico da Universidade Federal do Paraná (PPGDE/UFPR). Professor Adjunto de Ciências Econômicas da Faculdade de Educação Superior do Paraná (FESPPR). E-mail: casonato.economia@gmail.com

2 Doutor pela Université de la Sorbonne Nouvelle Paris III (1997). Pós-doutor pela Université de Picardie Jules Vernes, Amiens (2008); pelo Department of Economics and Lemann Institute for Brazilan Studies, da University of Illinois at Urbana-Champaign, Estados Unidos (2015-2016) e pela Faculdade de Economia, Administração e Contabilidade da Universidade de São Paulo (2017). Professor no Departamento de Economia e no Programa de Pós-Graduação em Desenvolvimento Econômico da Universidade Federal do Paraná. Presidente da Associação Brasileira de Pesquisadores em História Econômica (2011-2013). E-mail: ajdcosta@uol.com.br 
presents an introduction to the Neoclassical Theory of the firm, and discusses how it is understood and criticized by Penrose and Kirzner. From there, he reviews the theory proposed in Penrose's book, analyzing how her's conclusions are necessarily dependent on the methodological paths covered by her, to anthropomorphize in the firm the entrepreneurial actions that are the exclusive character of homo agens. This work observes that Penrose, following a methodology that is not very well defined, and which is not even expressed by her, ignores the subjectivism and individualism defended by the Austrian School, ends up proposing no more than a unilateral reading of the firm, from a managerial perspective, looks at companies from the inside out, in pursuit of profit opportunities, but that incurs the mistake of leaving aside the essential feature of the market process, i.e. entrepreneurial competition.

Keywords: Firm theory. Methodology. Penrose. Kirzner.

\section{Introdução}

A publicação do livro "Teoria do Crescimento da Firma" [1959] $]^{3}$ pode ser vista como um dos grandes marcos para o campo de pesquisa heterodoxo em microeconomia na Ciência Econômica. Segundo Melo (2002, p. 4), conquanto a validade das teses ortodoxas já estivesse em discussão desde o início do século XX, principalmente pelas críticas levantadas por Sraffa [1926], Robinson [1933] e Chamberlin [1933], essas ideias foram entendidas e reformuladas para dentro do mainstream do pensamento em seus próprios termos, de modo que, no lugar de vingarem como opositoras, acabaram internalizadas por parte daquele programa de pesquisa.

Com a publicação de sua obra, Penrose torna-se referência para diversos pesquisadores descontentes com o arcabouço teórico predominante que, ao considerar apenas os aspectos maximizadores nas decisões dos agentes econômicos, não abria espaço para as decisões empresariais (visão kirzneriana) ou gerenciais (visão penroseana) na explicação do crescimento das firmas, ou mesmo para as diferentes estratégias que elas seguiriam durante o processo competitivo. Dessa forma, de acordo com Pondé (1993), as ideias de Penrose tornaram-se parte da gênese da vertente microeconômica da economia evolucionária, voltada ao crescimento e desenvolvimento das empresas ${ }^{4}$.

Porém, todo esse desdobramento teórico ocorreu em linhas próprias, tendo como base diversas contribuições de Schumpeter, principalmente com base na ideia

3 Os anos apresentados em colchetes referem-se aos das publicações originais das obras mencionadas, para contextualizá-las historicamente.

4 "Empresa" em Kirzner (2012) refere-se ao empreendimento levado a cabo pelo indivíduo, e não usa o termo "firma". Em Penrose (2006), o termo empresa também tem essa conotação, mas é igualmente usado para se referir às firmas. Neste ensaio, eles são utilizados como sinônimos. 
do empresário inovador, apresentado pela primeira vez em seu livro seminal "A Teoria do Desenvolvimento Econômico" [1911]. De acordo com Baptista (1997, p. 44), além de ignorar a economia tradicional, com base em Penrose, essa linha de pesquisa dá início ao ramo neoschumpeteriano da microeconomia, tomando as firmas como heterogêneas em suas composições, em suas decisões empresariais e em seus objetivos como participantes do sistema econômico.

Segundo Pondé (1993), diversos outros autores, mais ou menos próximos a esse grupo, também propuseram críticas às teorias da firma, seja da tradicional ou das alternativas, com destaque para Ronald Coase [1937], Oliver Willianson [1979] e Alfred Chandler [1990] por suas contribuições originais e de grande impacto na literatura econômica sobre o tema.

Coase e Willianson opuseram-se tanto a visão Neoclássica quanto a neoschumpeteriana, ao darem foco ao aspecto legal da firma, encarando-a como uma rede de contratos entre os diversos agentes que atuam simultaneamente para originar um produto ou serviço. Já Chandler seguiu mais próximo da tradição penroseana, considerando o crescimento da firma como ponto de análise e adotando a perspectiva evolucionária, além de estender a percepção da importância dada ao interior da empresa e as causas do seu crescimento para suas consequências no sistema capitalista, buscando entender como a grande empresa modificava a dinâmica econômica dos países.

Uma visão radicalmente diferente destas foi proposta por Israel Kirzner, um seguidor da Escola Austríaca de Economia, tradição iniciada por Menger [1871], que fora muito próxima da economia Neoclássica em sua estruturação ao final do século XIX com a revolução marginalista (CALDWELL, 2004, p. 127). Kirzner propôs-se a traduzir os escritos de Ludwig von Mises [1949], seu orientador de doutorado, sobre a ação humana para dentro da teoria da empresa (que denominou teoria dos preços), conflitando-a com a teoria da competição perfeita, de modo que sua contribuição, segundo Kirzner explica, é inserir as ideias de ação humana no ambiente do mercado para tratar da competição empresarial.

Este artigo busca uma revisão que se pretenda original sob alguns pontos da "Teoria do Crescimento da Firma" de Edith Penrose à luz das contribuições de Kirzner como seguidor da Escola Austríaca. Tal originalidade se dá pela comparação entre os autores por meio da identificação metodológica que perseguiram, causa última das suas diferenças. Ambos partem de críticas à teoria Neoclássica em suas propostas, usando suas distinções com relação a ela como ponto de partida para suas explicações teóricas sobre o papel da empresa e/ou do empresário. A hipótese aqui admitida é de que Penrose falha ao não adotar um processo metodológico crível, que lhe permitiria ver ou apontar quão específica é a estrutura de sua análise. Isto será demonstrado mostrando que o foco dado pela autora já começa equivocado, ao adotar a firma como ponto de partida na proposição teórica, quando a escolha mais acertada seria do indivíduo, único agente econômico capaz de tomar 
decisões, que o faz exclusivamente na busca pela melhor satisfação dos seus próprios objetivos.

0 restante deste trabalho é dividido em outras cinco seções. A próxima apresenta a teoria da firma como era concebida até 1970, portanto o foco das críticas de Penrose e Kirzner, e resume os pontos de desacordo desses autores com relação a ela. As seções três e quatro discutem, respectivamente, as contribuições de Penrose e Kirzner sobre empresários, firmas e concorrência no mercado. Já a quinta destaca as diferenças metodológicas entre esses autores, mostrando a raiz das diferentes interpretações que têm da economia, enquanto a sexta e última seção apresenta as considerações finais do artigo.

\section{Definindo o espantalho: a teoria Neoclássica da firma}

Esta seção oferece uma introdução da ideia de competição como entendida pela economia Neoclássica até a década de 1970, a partir das contribuições de Louis Makowski e Joseph Ostroy, autores que se debruçaram amplamente sobre a Competição Perfeita nas décadas de 1980 e 1990, na busca pela sua reformulação para responder as diversas críticas que lhe foram levantadas, entre elas a de Kirzner, já que os autores apontaram haver uma confusão entre a ideia original de competição perfeita da teoria tradicional e desta como hipótese para o modelo de equilíbrio geral na economia Neoclássica.

Os autores mostram (2001, p. 479) como a revolução marginalista realizada por Jevons [1871], Menger [1871] e Walras [1874] promoveu uma ruptura com a escola clássica, dando novo direcionamento às pesquisas da Ciência Econômica ao permitir a criação das bases microeconômicas da teoria da firma que prevalecem até hoje. Porém, quando analisadas individualmente, cada uma dessas contribuições permitiu que seguissem linhas de pesquisa distintas, seguidoras das demais concepções que tinham cada um dos precursores dessa revolução marginalista, como se vê na Escola Austríaca, seguidora de Menger, e nos desenvolvedores do Equilíbrio Geral, inspirados em Walras.

Segundo os autores (2001, p. 491), não seria até a década de 1970 que os economistas teriam uma preocupação em reformular os conceitos adotados em suas hipóteses para revisitar essas questões na formulação dos seus modelos. Makowski e Ostroy (2001, p. 492) entendem que a nova perspectiva nascida daí teve como base a reconsideração do caráter e do papel da informação no processo econômico, pela influência direta das diversas críticas sobre a questão do conhecimento nos modelos de competição. Os autores sugerem (2001, p. 479) que essas críticas poderiam ser agrupadas em uma síntese: falta o elemento criativo no mercado concebido pela escola Neoclássica. Apontam, ainda, que essa ausência é originada na hipótese de que os agentes econômicos são tomadores de preço, suprimindo qualquer elemento de decisão deliberada na concorrência perfeita. 
Deste modo, argumentam (2001, p. 480) que foi descartada pela teoria da Competição Perfeita o princípio de processo concorrencial, que era uma das inspirações dos autores clássicos, presente já nas obras de Smith, em que a concorrência dos indivíduos, na busca por atender seus próprios interesses, promoveria a eficiência econômica. Isto resultou na consideração de um mercado passivo e de agentes reativos a mudanças exógenas.

The behavioral postulate linking individual choice to marginalism is pricetaking. The individual (household or firm) chooses quantities to maximize utility or profit, taking prices as given. In the hands of the early marginalists, price-taking proved a very convenient simplifying assumption for displaying the new equi-marginal principle underlying optimal choice; in this respect, it was a servant of marginalism. It had the unfortunate consequence, however, of suppressing the more entrepreneurial aspects of economic behavior (MAKOWSKI; OSTROY, 2001, p. 483).

Makowski e Ostroy (2001, p. 483) discorrem sobre esse problema, defendendo que teria surgido do fato de os teóricos da competição basearem-se nos desdobramentos das ideias walrasianas sobre o equilíbrio geral, uma vez que o autor estaria originalmente preocupado em saber como os agentes econômicos reagiriam às mudanças nos preços de uma economia como sistema fechado. Portanto, nessa via de análise, os preços precedem as escolhas alocativas dos indivíduos. Mas, como Walras reconhecia o problema, postulou que no caminho para o equilíbrio geral os preços seriam descobertos por duas vias: (i) considerando-os como resultado das ações individuais e; (ii) por meio do "tâtonnement" ("tatear", em francês), em que os agentes estão a todo o tempo "tateando" os mercados na busca dos preços finais, o que implicaria algum processo de descoberta.

Porém, seguindo esse traço argumentativo, não seriam os agentes econômicos responsáveis por equilibrar o mercado através das suas ações, mas as forças exógenas "de mercado" é que o promoveriam através dos excessos de demanda e oferta.

Strict adherence to the rule that prices precede maximization, both in and out of equilibrium, means that individuals are not responsible for equilibrating markets (it is not an optimizing decision). Rather, the detection and correction of disequilibrium is delegated to market forces, responding impersonally to excess demands and supplies. Sometimes these forces are anthropomorphized in the form of an exogeneous, benevolent "Walrasian auctioneer," who adjusts prices until markets clear (MAKOWSKI; OSTROY, 2001, p. 483).

Segundo os autores (2001, p. 484), essa explicação já teria sido contestada por Kenneth Arrow em 1959, que afirmara que nessa narrativa não havia espaço para decisões de agentes individuais, racionais em relação aos preços e às quantidades objetivadas. Portanto, mesmo entre os seguidores da linha Neoclássica do processo 
competitivo, não se tinha consenso sobre o funcionamento da competição perfeita, pela impossibilidade de identificar dentro das constatações dessa teoria o que seria causa e o que seria consequência.

Muitas são as objeções levantadas à teoria padrão de concorrência. Em especial, de interesse do objeto aqui pretendido, destacam-se as oposições apontadas por Kirzner. Mesmo a crítica mais forte da Economia Austríaca à teoria dos preços é reconhecida por Makowski e Ostroy, quando afirmam (2001, p. 484) que a principal falha do modelo padrão é justamente a falta de um componente de competição. Apontam (2001, p. 486) que o principal descontentamento de Kirzner [1973] seria o da ênfase no equilíbrio, quando a explicação deveria ser sobre como esse ponto é atingido no mercado, por meio das variações de quantidades e preços.

O próprio Kirzner (2012, p. 11) delineou com clareza, ainda no prefácio de seu livro, uma forte oposição aos desdobramentos teóricos considerados pelos pesquisadores da teoria tradicional dos preços e da concorrência, na sua proposta de análise do processo de mercado à luz da Economia Austríaca.

A visão kirzneriana não abandona o interesse no mercado e em seus participantes, antes, adota como foco o processo pelo qual a economia caminha ao equilíbrio, tirando os holofotes desse último, diferente da teoria tradicional, que analisa como a economia sai de um estado estacionário a outro por meio de mudanças dadas exogenamente (KIRZNER, 2012, p. 16). Portanto, o que Kirzner (2012, p. 17) está buscando é uma saída (ou alternativa) ao problema decorrente das ideias de informação sobre preços e quantidades já disponível, bem como dos agentes maximizadores reagentes a eles e suas mudanças, para um ponto de vista em que esses indivíduos de fato agem espontaneamente e modificam o ambiente nos quais estão inseridos.

\footnotetext{
Essa situação de equilíbrio de mercado é certamente uma situação onde a competição não é mais uma força ativa. A cessação do processo de mercado que é uma característica do estado de equilíbrio, é a cessação do processo competitivo. É contra o pano de fundo dessa noção de competição, onde a competição é inseparável do próprio mercado, que criticarei mais tarde a utilidade de noções que confinam a competição à situação onde o processo de mercado cessou - o estado de equilíbrio (KIRZNER, 2012, p. 22).
}

O ponto central da crítica de Kirzner (2012, p. 34) às análises voltadas ao estado de equilíbrio está no fato de que elas desconsideram o papel empresarial exercido pelos agentes no mercado. Ainda mais, ao considerar apenas os movimentos transitórios entre diferentes pontos de equilíbrio, a teoria tradicional acaba por tomar o processo econômico como estático, deixando de lado o caráter dinâmico e subjetivo envolvido nas decisões de comprar, vender e concorrer entre os agentes que participam do mercado. Tomar as escolhas dos agentes pelo 
princípio da maximização ignora que muitas decisões se baseiam em eventos expectados, que por vezes os prognósticos individuais estão pautados em ganhos futuros, e que mesmo os caminhos a serem percorridos para um mesmo fim podem diferir entre os agentes, sejam firmas ou famílias, já que a informação é dispersa e sua interpretação dependente de características cognitivas individuais.

A visão penroseana também se contrapõe à necessidade da consideração do equilíbrio na teoria tradicional da firma, apontando como objetivo central dessa última a predição dos movimentos econômicos advindos de uma perturbação exógena na interação dos mercados, a qual, inicialmente é tomada sob o pressuposto do equilíbrio no mercado, do seu funcionamento competitivo e de sua promoção do bem-estar. Nessa perspectiva, pouco ou nenhum interesse seria dado ao interior da firma, a suas estratégias de competição e crescimento, tomando-a simplesmente como a contraparte produtiva dos indivíduos econômicos que também promoveriam o equilíbrio por meio da busca pela satisfação dos seus interesses, o que foi tomado como a maximização dos lucros (PENROSE, 2006, p. 11 - prefácio da terceira edição, 1995).

Como esse tópico não foi objeto de análise pelos economistas teóricos da perspectiva tradicional, sua ocorrência foi tomada como um ajuste automático feito pela empresa, necessariamente realizado pelas firmas às condições enfrentadas por elas para sua sobrevivência no ambiente competitivo (PENROSE, 2006, p. 32). Mas, essa ideia nada mais faz do que traduzir a empresa como uma função de produção, que detém um equilíbrio interno, de fins e meios, por meio do equilíbrio externo, de acordo com a disposição de todo o sistema econômico, dos quais advém a quantidade total de cada bem a ser produzido e os respectivos preços, em que cada firma encontrará seu tamanho ótimo por intermédio de sua estrutura de custos. Dessa forma, essa abordagem é completamente incapaz de tratar uma firma como caso isolado de suas possibilidades de ação dentro do mercado ou de suas ideias de como melhor alcançar seus objetivos, tal que não dá conta de tratar do crescimento da firma (PENROSE, 2006, p. 44).

O problema é que a pressuposição do equilíbrio inicial é uma das condições centrais para a teoria Neoclássica, mas isto parte da consideração inicial de que há certo ponto, do qual os recursos da firma são indivisíveis, tais como os administrativos, sobre os quais versará a discussão central de Penrose, de modo que a empresa não possa ter maiores ganhos de eficiência ou menores custos por meio de uma estrutura mínima já estabelecida, assim como ignora o processo dinâmico envolvido na concorrência no mercado. Segundo Penrose:

As condições da análise do equilíbrio requerem que haja algo que impeça a indefinida expansão da produção da "firma" individual [...]. No modelo da firma em concorrência "pura", o limite à produção só é encontrado no pressuposto de que o custo de produção de um produto individual deve aumentar a partir de certo ponto, à medida que 
quantidades adicionais do produto vão sendo produzidas. No modelo da firma em concorrência "monopolística", o limite é parcialmente encontrado em receitas decrescentes, à medida que maiores quantidades do produto são vendidas. Sem algum limite desse tipo a produção de dado produto - o qual, no presente contexto, equivale ao tamanho da firma - nenhuma "posição de equilíbrio" determinada pode ser postulada em termos de uma teoria estática (PENROSE, 2006, p. 45).

Portanto, além das questões do equilíbrio, é na incapacidade da teoria Neoclássica em lidar com a ausência de racionalidade completa ou com a possibilidade de conhecimento imperfeito que torna limitada sua compreensão do papel exercido pelos recursos administrativos, já que considera objetivo e igualmente distribuído um conhecimento que é subjetivo e escasso, disputado e muitas vezes diferentemente interpretado pelos agentes do mercado (PENROSE, 2006, p. 103), pontos que encontram reforço também em Kirzner (2012).

Ainda mais, segundo Penrose (2006, p. 45), a teoria tradicional considera custos crescentes na produção de longo prazo pelo esgotamento do uso desses recursos administrativos, ou as receitas decrescentes pelos limites de absorção do mercado. Essa visão de limitação das atividades da firma, segundo a autora (2006, p. 46), surge do pressuposto de que cada empresa está estritamente ligada a determinados produtos, e que as relações entre diferentes mercados conduzem a existência de oportunidades de expansão nesses segmentos.

Desta maneira, ao despir as firmas de suas características competitivas e/ou exclusivas, a teoria Neoclássica toma-as como iguais, e não se interessa, e nem é capaz de explicar, como cada uma delas encontra-se no estágio de crescimento em que está ou aqueles que lhe são possíveis, tomando-os como reagentes ao sistema de preços e quantidades, excluindo-lhes a capacidade de mudança deliberada desse conjunto (PENROSE, 2006, p. 237).

Dessa discussão é possível perceber que tanto Penrose quanto Kirzner convergem nas críticas à economia Neoclássica em algumas questões centrais, tais como: (i) adoção das hipóteses sob o conhecimento, que tem de tratá-lo como objetivo e de disponível acesso; (ii) dependência do equilíbrio como ponto de partida, que tem como resultado ignorar a vontade e as ações deliberadas dos diferentes agentes econômicos, além de desconsiderar o papel dinâmico do processo de mercado e as decisões empresariais tomadas ao longo do tempo.

Porém, por mais que essas críticas estejam na grande maioria alinhadas, as propostas de soluções para esses problemas teóricos diferem de diversas maneiras, já iniciando pelo foco de análise adotado quanto ao tomador de decisões para seus respectivos desdobramentos teóricos. Segundo Penrose:

Numa economia industrial de empresas privadas, a firma mercantil constitui a unidade básica de organização da produção. A maior parte das atividades econômicas é realizada 
por meio de firmas. Os padrões da vida econômica, incluindo tanto os padrões de consumo como os de produção, são em boa parte moldados pela multidão de decisões individuais tomadas pelos homens de negócios que orientam as ações das unidades mercantis que chamamos de firmas. [...] Trata-se de instituições complexas que influenciam a vida econômica e social de diversas maneiras, envolvendo numerosas e diferentes atividades, tomando uma ampla variedade de decisões significativas, influenciadas por caprichos humanos múltiplos e imprevisíveis, embora geralmente orientados pela luz da razão (PENROSE, 2006, p. 41).

Mas, aqueles interessados em destrinchar as atividades da firma encontrarão nas ideias penroseanas o papel central da vontade dos indivíduos em suas ações? Encontrarão as deliberações tomadas individualmente na busca pelo atendimento aos seus próprios fins? Essa linha adotada pela autora de tomar a firma como foco de análise sugere que não. Kirzner alerta sobre os problemas dessa escolha metodológica:

\begin{abstract}
A ênfase na empresa (que, na nossa opinião, deve ser vista como uma combinação de empresário e proprietário de recursos) levou também ao fracasso em reconhecer a importância da pura propriedade de recursos para assegurar posições de monopólio na produção. 0 monopólio passou a ser associado à empresa e daí, infelizmente, ao empresário (KIRZNER, 2012, p. 34).
\end{abstract}

Portanto, este trabalho está se valendo da diferença inicialmente encontrada entre Penrose e Kirzner, a dicotomia aparente entre firma e empresário, já que a autora pretende dar maior ênfase nesse tipo de organização individual, entre empresário e fatores de produção, a empresa, enquanto Kirzner pauta-se pelas decisões individuais, que denomina empresariais, na busca que cada agente faz da satisfação dos seus interesses.

Esse ponto já começa a delinear a diferença quanto a natureza do conhecimento que será discutida ao final do artigo. Kirzner, como seguidor da Escola Austríaca de Economia, pauta-se na proposta teórica de Mises (2010), ao pretender analisar o processo competitivo por meio dos agentes individuais que agem deliberadamente, enquanto Penrose não apresenta proposta metodológica, permitindo-se partir de algumas hipóteses elaboradas com base na realidade que ela observava, e daí discutir as possibilidades de crescimento para uma firma individual.

\title{
3. Começando do fim: as conclusões da "Teoria do Crescimento da Firma"
}

À guisa de conclusão de seu livro, Penrose (2006, p. 381) apresenta nove pontos derivados da discussão que estabelece ao longo da obra, afirmando serem 
provenientes de questões que acredita não serem passíveis de resposta pela teoria Neoclássica da firma. Essas considerações são:

1. Uma firma não apresentará necessariamente deseconomias de escala a partir de um determinado tamanho máximo. Sua organização pode ser rearranjada de modo que se torne uma firma financeira, ou equivalente, cuja estrutura produtiva passa a ser um dos ramos da firma maior (PENROSE, 2006, p. 381).

2. Uma firma não possui essencialmente economias de escala na relação entre setor produtivo e estrutura administrativa. É possível que se aumente a eficiência do setor organizacional para permitir a diminuição da administração da empresa (PENROSE, 2006, p. 381).

3. A possibilidade de crescimento da firma independe do tamanho que ela possui. 0 que existe são vantagens e desvantagens relativas ao porte da empresa, mas ela sempre pode crescer (PENROSE, 2006, p. 382).

4. Todas as firmas possuem oportunidades de crescimento, baseadas no uso eficiente dos recursos (PENROSE, 2006, p. 383).

5. Não haverá perda de eficiência da firma, nem das suas divisões produtivas, se ela estiver voltada ao gerenciamento descentralizado dos diversos ramos em que atua, conquanto essas partes produtivas possuam autoridade para funcionar com independência. Em resumo, a descentralização da produção e das decisões gerenciais permitem ganhos de eficiência (PENROSE, 2006, p. 383).

6. Apesar da infinidade das possibilidades de crescimento das firmas, há um limite às taxas desse crescimento, cuja amplitude será inversa ao seu tamanho. Quanto maior a firma vai ficando, menor a taxa na qual ela irá crescer (PENROSE, 2006, p. 384).

7. As restrições artificiais ao crescimento das firmas implicam ineficiência no uso dos recursos econômicos (PENROSE, 2006, p. 384).

8. A defesa da busca pelo crescimento das firmas surge das vantagens que essa estratégia proporciona internamente, ao promover maiores oportunidades de lucros, e externamente, ao permitir mais produtos e tecnologias no processo competitivo com outras firmas. Mas essa defesa só é mantida até o ponto em que elas possam tornar-se grandes demais, quando tiverem poder de mercado suficiente para impedir as vantagens externas, ou seja, até que elas tenham um tamanho que permita-lhes impedir o livre processo concorrencial (PENROSE, 2006, p. 384). Mas, isto entra em conflito quando existe uma necessidade de um arcabouço institucional que garanta os ganhos dos investimentos em pesquisa e desenvolvimento realizados pelas firmas, já que se sustenta que elas só farão os devidos investimentos nessas áreas se tiverem assegurados os retornos permitidos. Portanto, ocorre uma contradição entre causa e 
consequência na concorrência: a causa é o não favorecimento institucional de nenhuma firma, garantindo-se que haja competição entre elas; mas, como consequência, tem-se que elas só irão concorrer se puderem apropriar-se exclusivamente de seus investimentos, de modo que alguma contingência institucional é requerida para proteger os produtos exclusivos dessas firmas, o que impediria a concorrência nesse segmento - um dilema sobre os direitos de propriedade intelectual (PENROSE, 2006, p. 385).

9. Conquanto não haja limites para a taxa de crescimento das firmas ao longo do tempo, em qualquer instante específico essa taxa estará limitada pelas contingências internas e externas enfrentadas pela firma. Como as grandes firmas criam diversas oportunidades de ganhos econômicos quando atuam no mercado, elas buscam aproveitá-las, mas não há garantia de que outras não o farão. Se tentarem valer-se de restrições artificiais para desfrutar dessas oportunidades, que não através do processo de mercado, não estarão limitando apenas o crescimento das demais firmas, mas também o de toda a economia (PENSORE, 2006, p. 385).

Essas conclusões ainda podem ser resumidas em três pontos principais nos quais Penrose está em descordo com a teoria tradicional: (i) não existe um tamanho ótimo da firma, tal que haja vantagens em atingi-lo ou desvantagens em ultrapassálo, pois uma firma sempre pode crescer, embora a velocidade do processo seja limitada por fatores internos e externos; (ii) a descentralização das atividades produtivas não implica necessariamente perda de eficiência pela divisão dos recursos administrativos e; (iii) as firmas não devem sofrer nem produzir restrições artificiais ao crescimento, próprio ou das demais, mas devem ter garantidas estruturas institucionais que assegurem a concorrência entre elas.

Os três pontos delineados acima serão objeto de análise no restante dessa seção e na próxima. Na subseção que segue eles serão explicados com base nas contribuições de Penrose (2006), e na quarta seção eles serão revisitados dentro da proposta de Israel Kirzner sobre a Competição e Atividade Empresarial (2012).

\subsection{A fundamentação dessas conclusões}

Essa subseção ainda será dividida em outras quatro partes, de modo a apresentar a definição de firma adotada por Penrose, bem como para fundamentar os três pontos elencados acima que resumem as conclusões de sua obra. 


\subsubsection{O que é a firma?}

No prefácio da terceira edição de sua obra, escrito em 1995, Penrose (2006, p. 20) faz um retrospecto daquilo que considerou como firma, definindo-a como unidade de planejamento, cujo cerne estava em congregar as atividades gerenciais e administrativas. Nesse sentido, ela é causa e consequência do mercado, e segundo a autora só é possível distingui-la desse último com a adoção das categorias de análise, já que não seriam passíveis de observação. Portanto, as fronteiras que a delimitam são tomadas como imposições adotadas a priori pelos pesquisadores.

Considerado esse grupo, impera saber os seus objetivos. Seu objetivo último é o lucro, mas o que guia suas atividades produtivas nesse sentido são as "oportunidades produtivas", que são as possibilidades passíveis de serem aproveitadas pela firma. A função da teoria pretendida pela autora é promover um exame dessas oportunidades, de tal modo que se possa encontrar como se dá o crescimento da firma (PENROSE, 2006, p. 72).

Mesmo creditada como seguidora de Schumpeter [1934], Penrose (2006) se distancia em muito da visão de empresário que era defendida por ele em sua obra pioneira sobre o papel empresarial no crescimento econômico, pela centralidade que ela dá à firma em detrimento do empresário. Schumpeter (1997, p. 88) defendia o empresário como promotor do crescimento econômico ao gerar inovação tecnológica em qualquer área das empresas, que permitisse romper com o padrão então prevalecente e torná-la mais eficiente que as demais, o que resultaria em uma revolução do mercado até que todas se adequassem a esse novo padrão, ou que fossem eliminadas no processo. Completamente diferente é a visão de Penrose (2006, p. 72, nota de rodapé), que relega ao empresário um papel gerencial, que no seu entendimento é apenas diferente do papel administrativo nessa perspectiva de deixar a cargo da firma a função de empreender no mercado, conquanto não aponte quem, necessariamente, resolve e age nessas questões. 


\subsubsection{Qual o tamanho ótimo da firma?}

Definido seu conceito de firma, uma preocupação de Penrose é discutir se há um tamanho ótimo como apontado pela teoria Neoclássica. Ocorre que a autora, ao sair da visão simplificada da empresa como uma função de produção, que agrega fatores produtivos por meio de uma determinada tecnologia, percebe que as diferenças de tamanho entre as empresas são tão grandes que por vezes uma comparação entre elas seria injusta, já que não se estaria partindo de um denominador comum (PENROSE, 2006, p. 54). Tome como exemplo a comparação entre um pequeno prestador de serviços, como um barbeiro que é proprietário-trabalhador em seu negócio, e uma grande corporação transnacional do ramo alimentício, que opera em diversos ramos e setores econômicos por meio da sua carteira de investimentos. É o tipo de exemplo que Penrose aponta como a comparação entre a lagarta e borboleta. Por isso a sua definição de firma, de delimitar um número de pessoas em um processo produtivo, é necessária, pois abstém-se de considerar a estrutura da empresa para dar foco naquilo em que ela é comparável às demais.

Isto se reforça com a definição de utilização de recursos pela empresa. Não são os trabalhadores e o capital empregado os responsáveis pela produção, mas os serviços que eles emprestam ao processo produtivo, o que expõe a diversidade de funções que um mesmo trabalhador ou máquina pode exercer em determinado contexto. Assim, é de responsabilidade da firma encontrar o melhor emprego para esses recursos (PENROSE, 2006, p. 62). Mas essa responsabilidade recai sobre os serviços administrativos, a grande chave para o entendimento da teoria penroseana:

\footnotetext{
São os serviços que tornam possível uma relação de trabalho entre determinados indivíduos tomando decisões e agindo dentro de um entorno específico; são eles que determinam a eficiência e a confiança com a qual ações podem ser empreendidas pelo grupo como um todo. A menos que tais serviços sejam prestados por seus membros, o grupo não pode funcionar como uma unidade (PENROSE, 2006, p. 91).
}

A hipótese básica adotada por Penrose (2006, p. 74) é de que as firmas estão sempre na busca por aumentar seu lucro, e como resultado tem-se o crescimento econômico. Nessa tentativa, buscam deliberadamente empreendimentos que permitam esses ganhos. Portanto, de início parece não haver contradição com a teoria Neoclássica da firma, porque enquanto houver possibilidade de lucro a empresa continuará crescendo, e esse processo só será interrompido quando não houver mais ganhos possíveis. Mas, enquanto a teoria tradicional está voltada a realização de uma atividade no mercado, com um produto, a firma penroseana é diversificada, se expande horizontal e verticalmente, de modo a obter vantagens competitivas em relação às suas concorrentes. 
A visão de crescimento adotada por Penrose também foge à análise convencional. A autora toma-a como um processo, enquanto o tamanho da empresa configura um estado, de modo que a análise do crescimento deve centrar na eficiência com que são utilizados os recursos disponíveis à firma, tal que o tamanho final seja o resultado disso (PENROSE, 2006, p. 147). Já para a teoria Neoclássica, o crescimento é tomado em análises estáticas, pela comparação entre dois tamanhos em seus respectivos pontos de equilíbrio, antes e depois do crescimento, sem analisá-lo ou explicá-lo em termos de decisões empresariais.

Esse crescimento na teoria penroseana é explicado pelo uso cada vez mais eficiente dos recursos administrativos disponíveis às empresas. Dessa forma, a economia Neoclássica teria visto apenas um aspecto do processo, o do crescimento de uma empresa quando ela pode produzir maior quantidade a custos mais baixos por meio dos ganhos de escala (PENROSE, 2006, p. 154). Mas isto não é suficiente, já que existem diversas outros meios e motivos para o crescimento, tais como: (i) as vantagens advindas de ser uma empresa maior em relação às menores, na introdução de novos produtos e/ou tecnologias no mercado (PENROSE, 2006, p. 148); (ii) os menores custos possíveis pela diversificação da produção, cuja realização reduz seu custo médio pelos ganhos de escala com a utilização dos mesmos serviços gerenciais e/ou administrativos usados anteriormente (PENROSE, 2006, p. 161); (iii) os ganhos de eficiência produtiva por intermédio da integração vertical, eliminando friç̧ões entre as etapas do processo produtivo, em qualquer ponto entre a extração do insumo até a venda do produto final (PENROSE, 2006, p. 169); (iv) as vantagens adquiridas pelas firmas mais antigas, já que sua consolidação ao longo do tempo permite experiência (conhecimento) no enfrentamento das situações adversas (PENROSE, 2006, p. 323) etc.

0 que esses quatro pontos acima têm em comum são as vantagens geradas pelos recursos administrativos das firmas, cujo aumento de eficiência permite se desdobrarem para novas áreas e funções. Mas esses ganhos são considerados em relação aos seus custos, é o que Penrose denomina "recursos administrativos por dólar de expansão", em que a expansão da firma pode ser causa ou consequência do uso mais eficiente dos recursos administrativos, dada a necessidade de que eles se ajustem às novas demandas, sejam elas percebidas para expansão a ser realizada ou impostas pela expansão já concretizada:

Os requisitos administrativos por dólar de expansão dependem: a) do caráter da própria expansão; b) da relação entre o tipo de expansão, as atividades correntes da firma e o complexo de circunstâncias externas que denominarei simplesmente como "condições de mercado"; e c) do método de expansão (PENROSE, 2006, p. 306). 
Portanto, como consideração deste tópico, na perspectiva penroseana percebe-se que não há um tamanho ótimo ao qual a firma deve ser limitada, pois mesmo que esgotadas as possibilidades de crescimento em seu ramo produtivo ela ainda pode migrar para outros, sejam eles em áreas complementares a sua, através da diversificação vertical ou horizontal, ou mesmo para áreas completamente diferentes, desde que possuam alguma base administrativa para encarar os novos desafios.

E essas oportunidades sempre estarão disponíveis, independentemente do tamanho das firmas, porque Penrose considera que os movimentos econômicos geram oportunidades que denomina "interstícios", em que as grandes empresas são incapazes de atender sua demanda, abrindo espaço para as menores o preencherem (PENROSE, 2006, p. 330). Mesmo o crescimento dessas grandes firmas gera esses "interstícios", pois todo o movimento que realizam em direção à expansão vão gerando novas oportunidades de lucros, disponíveis de captura pelas outras empresas presentes no ambiente competitivo, já que não há nenhuma garantia de que a própria firma, que gerou a oportunidade, será capaz de enxergá-la ou capturá-la (PENROSE, 2006, p. 332).

\subsubsection{Por que há relação direta entre descentralização e eficiência?}

Se não há tamanho ótimo, a firma estará em constante expansão durante a sua existência, mesmo que se intercalem aí períodos com crescimento zero ou decrescimento, já que a tendência à expansão sempre estará presente. Assim, a eficiência desse processo só pode ser garantida pela independência das decisões administrativas que deem caráter dinâmico ao processo gerencial, impedindo o engessamento das decisões em uma estrutura centralizada, o que, de acordo com Penrose (2006, p. 126), é eficientemente alcançado com a descentralização, tal que descentralizar e crescer tornam-se faces da mesma moeda, já que ambas têm como raiz a divisão do trabalho.

Isto é decorrente da existência de diversas oportunidades simultâneas para a expansão da firma, mas com apenas uma parte delas podendo ser aproveitada por ela mesma, por conta da sua limitação de recursos disponíveis. Como cada uma dessas oportunidades é encarada como um desafio, tem-se nelas uma composição de incentivos e dificuldades a serem enfrentadas, tanto dentro como fora da firma, criando maior ou menor possibilidades de lucros, tal que sempre se está diante de uma análise dos custos de oportunidade (PENROSE, 2006, p. 117).

Essas opções, uma vez delimitadas à expansão da firma através de atividades produtivas, podem ser apresentadas pelos tipos de diversificação disponíveis apontados por Penrose. Vale notar que mesmo que se apresentem numa diversidade de formas, o foco central da diversificação é que a firma o realiza sem deixar de operar no setor que atuava anteriormente, tal que não há mudança de atividade, apenas a incorporação de novas, variando as atividades finais da empresa 
(PENROSE, 2006, p. 175). Dentre os diversos tipos de diversificação considerados pela autora, estão: (i) de mercados, em que a expansão ocorre para o atendimento de novos públicos, sejam eles nacionais ou internacionais; (ii) de produtos para um mesmo mercado, aproveitando-se da influência que já exerce sobre aqueles demandantes com os bens já anteriormente estabelecidos, e/ou das estruturas produtivas ou distributivas desses produtos (PENROSE, 2006, p. 177) e; (iii) com a aquisição das etapas intermediárias do processo produtivo (PENROSE, 2006, p. 225).

Os dois primeiros pontos são conhecidos como diversificação horizontal, enquanto o terceiro é estabelecido como integração vertical. Ambos permitem novas capacidades à firma, e a dificuldade adicional de gestar um novo negócio. Ocorre, porém, que nem sempre é preciso a firma iniciar em um novo ramo com desconhecimento total do mercado. Conquanto ela tenha diversas vantagens administrativas e de recursos, já que é suficientemente estabelecida em seu ramo para poder imergir em novas áreas, segundo Penrose (2006, p. 201), ela pode reconhecer a incapacidade de comprar conhecimento, já que ele é disperso e inerente às atividades próprias realizadas pela firma, e propor-se a "comprar" os conhecimentos inseridos nos serviços dos fatores de produção, por meio do processo de aquisição de negócios. Assim, através da aquisição, uma firma pode expandir-se e superar parte dos desafios iniciais de entrada em um novo ramo.

Qualquer que seja o caminho escolhido, ele incorrerá em custos, e é o enfrentamento desses custos que vai ficando cada vez mais caro à firma conforme ela expande, dada a limitação dos seus recursos administrativos, e por isso a diversificação é uma estratégia interessante, já que permite que novos núcleos administrativos independentes venham a gerir as oportunidades encontradas por cada ramificação diversificada da firma, independendo de uma decisão central que pode não deter o conhecimento necessário para as melhores escolhas, dada a distância com os diversos produtos finais que comercializa.

\subsubsection{Há contradição sobre as imposições artificiais ao mercado?}

As conclusões de Penrose (2006) parecem sugerir uma contradição quanto às imposições artificiais ao mercado, aquelas que seriam criadas e sustentadas de forma a distorcer seu funcionamento como processo competitivo, porque a autora defende que elas devem ser evitadas pelo prejuízo que trazem às firmas, ao passo que sustenta a necessidade de um arranjo institucional que garanta a apropriação de ganhos pelas inovações das empresas como forma de incentivo a continuarem promovendo progresso tecnológico, o que também é uma imposição artificial ao mercado, que passa a ter excluída a concorrência no nicho protegido por tal arranjo.

Conquanto o surgimento da problematização das questões artificiais na concorrência de mercado não fosse contemporâneo à publicação de Penrose [1959], 
o ponto alto dessa discussão o foi. Isso porque o tema ganha grande destaque com as publicações de Joe Bain [1956] e Paolo Sylos-Labini [1957], ao discutirem os pormenores das formações e manutenções de oligopólios, com grande destaque à discussão das barreiras à entrada nos modelos de concorrência então admitidos.

Bain (1956) e Sylos-Labini (1986) ocuparam-se da discussão de como os diferentes tipos de mercados produziam e mantinham determinadas barreiras. Considerando um modelo de competição mais concentrado que os da concorrência perfeita e imperfeita da teoria Neoclássica, discutiram os arranjos oligopolistas e a possibilidade inerente da grande firma em sustentar barreiras à entrada em determinados mercados, via preços e quantidades por ela praticados, de forma a tornar mais ou menos lucrativa a entrada de competidores nos setores em que essa grande firma estaria atuando.

Mas esses autores estavam preocupados com o poder de mercado da firma, apenas uma parte da discussão penroseana, sobre a possibilidade de grandes empresas se imporem para impedir o processo competitivo. Tal como já discutido anteriormente, Penrose (2006, p. 323) afirma as vantagens competitivas das firmas mais antigas e/ou maiores, por conta da sua situação como empresa consolidada no mercado, posse de recursos administrativos experimentados e maiores possibilidades financeiras, acesso ao crédito etc.

A boa fé de Penrose quanto ao advento das pequenas firmas encontra-se na ideia dos "interstícios" do mercado, como já apresentado, em que, na ausência de barreiras artificiais, qualquer firma competente poderia prosperar:

O desenvolvimento e a persistência da concentração produtiva numa economia em crescimento dependem do número e do tipo de interstícios criados e da capacidade das pequenas firmas de penetrar e de crescer nesses interstícios. 0 primeiro fator deriva em boa parte da natureza e do grau de concorrência entre as firmas maiores, enquanto o segundo depende das barreiras à entrada e das práticas de aquisição (PENROSE, 2006, p. 337).

Mas, quando da ocorrência de tais barreiras que restrinjam o ingresso de novas empresas no mercado:

[...] pode-se presumir não apenas que o ingresso dos concorrentes sempre seria lucrativo, mas também que a expansão resultante do referido campo envolveria um uso eficiente dos recursos do ponto de vista da economia como um todo. Os acessos impedidos significam, então, que recursos poderiam ter sido mais lucrativamente empregados precisam ser desviados para alternativas de menor alcance, as quais, presumivelmente representam maneiras menos desejáveis de uso dos recursos da economia (PENROSE, 2006. P. 343).

Porém, esse é um ponto de fácil entendimento, no qual não é necessário alongar a discussão, tal que um resumo é suficiente: qualquer barreira artificial 
mantida pela firma atrapalha o ambiente competitivo, as possíveis concorrentes, a própria firma, e o mercado como um todo.

A questão torna-se mais complicada quando é necessário garantir o pleno funcionamento da competição, o segundo ponto dessa discussão. 0 problema é: se essas estratégias concorrenciais pautam-se em restrições artificiais criadas pelas firmas, e precisam ser evitadas, como impossibilitá-las sem a criação de novas barreiras artificiais? Ou ainda, se esse é um resultado do mercado, conquanto eficaz, mas não eficiente, como sua correção pode ser defendida pela imposição de um arranjo institucional estabelecido sem o mercado, imposto de fora para dentro? Não é essa solução também uma imposição artificial? Por que ela é melhor do que a anterior?

Como as firmas estão disputando os ativos disponíveis, as que detiverem seu controle determinam os rumos do mercado, por meio da sua concessão. Penrose (2006, p. 255) demonstra isso ao utilizar o exemplo das firmas Alfa e Beta, sua relação entre si e as respectivas de cada uma com o mercado. 0 que a autora determina é que a fonte dos lucros monopolísticos está no proveito das fontes dos recursos necessários à geração de excedente no mercado. Portanto, as firmas detentoras definem sua lucratividade ou a das firmas que trabalham esses recursos, tal que a restrição de novas empresas nos setores dependentes desses ativos pode ser controlada.

Muito do que Penrose (2006, p. 350) sugere para o impedimento desse problema está pautado na proteção de direitos de propriedade intelectual. Mas a autora reconhece que mesmo isto pode ser prejudicial para a economia, pois pode ocorrer o caso da firma detentora dos direitos não ter capacidade, por maior que seja, de usufruir dos ganhos possíveis pela posse dos recursos, o que seria ruim para toda a sociedade.

Assim, a conclusão número oito de Penrose (2006, p. 385) é problemática, porque aponta a necessidade de se proteger a concorrência no mercado, mas a deixa em aberto, sem uma solução. Parece que a autora está sugerindo que o mercado deva passar por algum crivo de regulamentação, conquanto apenas aponte o porquê, mas não por quem e como, deixando em aberto a discussão de que mesmo essa solução pode acarretar problemas que podem ser mais custosos do que permitir as tais barreiras artificiais.

\section{A Ação empresarial na visão austríaca: a contribuição de Israel Kirzner}

Para Kirzner (2012, p. 16), a necessidade de substituir a teoria do preço por uma visão que compreenda a "Competição e Atividade Empresarial" como ele defende, decorre do erro inicial sobre o significado de mercado e sobre as implicações daí retiradas: que ele seja um conjunto padronizado de decisões entre os agentes que, na busca por atenderem seus desejos, estes anteriormente 
conhecidos e alinhados à tecnologia disponível e dotação inicial de recursos, fazem a economia caminhar na direção de uma quantidade de bens e serviços necessários à sua satisfação, ajustando-se os preços que permitem a situação mais satisfatória desses interesses, tendo como resultado o equilíbrio de mercado. Essa visão torna quantidades e preços como fatores passivos no sistema econômico, cujo ajuste às condições de equilíbrio ocorre sem maiores interferências, desde que as condições iniciais de informações sobre preferências, tecnologias e disponibilidade de recursos sejam satisfeitas.

Portanto, a diferença entre as vertentes já começa com a definição conceitual de mercado, que o autor (2012, p. 19) considera como o conjunto das decisões dos agentes econômicos interagindo em qualquer instante no tempo. Observa-se que não se trata apenas de ações efetivamente concretizadas, visto que também entram as intenções originais que podem ter sido frustradas pela ausência de situações expectadas. Ou seja, o mercado é constituído dos resultados das ações que aconteceram e das que não aconteceram, já que algumas ocorreram pela conformidade com os planos originais, enquanto outras ficaram a depender de oportunidades que não se realizaram, de modo que elas também não se concretizaram.

Kirzner (2012, p. 43) chega até mesmo a afirmar que a teoria do preço não estaria errada se as condições hipotéticas que admite fossem satisfeitas. Mas, não sendo, ela acabaria sempre por invocar uma explicação adicional, e é isto que o autor pretende prover com a ideia de Atividade Empresarial. Portanto, não se limita à inclusão de um novo componente nas características do agente econômico tratado na teoria do preço, antes, promove sua redefinição, assim como toda uma revisitação e reformulação de diversos conceitos utilizados, em especial: da informação, da competição, do empresário e do equilíbrio. Assim, não só corrige a teoria do preço, como promove um novo arcabouço para tratar da competição e do mercado conceitos que ele tratará como equivalentes.

É importante reconhecer a defesa do próprio autor (2012, p. 14) de que nenhuma dessas reconstruções teóricas lhe são originais, argumentando que só está expondo as contradições da teoria do preço e as soluções pertinentes por um outro ângulo, creditando às teses austríacas, em especial a de Ludwig von Mises, as respostas dadas aos problemas percebidos.

Esta seção propõe uma releitura das ideias kirznerianas sobre a Atividade Empresarial, considerando suas reconstruções dos conceitos assinalados (informação, competição, empresário e equilíbrio). Conquanto se reconheça que esses termos não são fatos isolados na teoria proposta, admitindo de início a interdependência entre eles, neste ponto a proposta é linearizar sua apresentação para melhor ilustrar a ligação entre eles, bem como introduzir de maneira didática a contribuição de Kirzner. Tal sugestão decorre do conceito de mercado adotado pelo autor ser condicionado pela interpretação dada à ideia de informação e sua 
distribuição entre os agentes, fatores que motivarão a competição, e em conjunto com o maior ou menor grau de atividade empreendedora que realizam, fator explicado pelo componente de atividade empresarial pura na ação do empresário, são determinantes do comportamento dos agentes no processo competitivo movendo a economia em uma tendência de direção ao equilíbrio.

\subsubsection{Informação}

A definição de mercado utilizada por Kirzner (2012, p. 19) é derivada do seu entendimento sobre a informação, esta fortemente baseada nas propostas teóricas sobre o conhecimento levantadas por Hayek (1948). Eles pressupõem que os agentes têm níveis de informações diferentes, e que cada um deles reage às modificações das condições vigentes de maneira única, tal que, a qualquer momento, os agentes estão interagindo no mercado, e cada uma das suas intenções vão sendo bem-sucedidas ou frustradas de acordo com as ações dos demais participantes, de modo que nesse processo todos vão reformulando seus planos sobre as melhores vias de satisfazerem suas preferências presentes nas intenções iniciais, e as atividades no mercado vão seguindo-se no tempo.

Com essa continuidade, cada reformulação de decisão e nova ação, concretizada ou impossibilitada, vão fornecendo novas informações a respeito do funcionamento do mercado, a disponibilidade de produtos e seus preços, fazendo com que todas as expectativas e planos sejam revistos pelo agente para buscar novos e melhores meios para seus fins. E isto se dá sem que tenham ocorrido mudanças nas condições iniciais anteriormente destacadas (preferências, tecnologias e dotação de recursos) (KIRZNER, 2012, p. 20).

Esse processo de reconstrução dos planos econômicos pelos agentes só é possível porque eles aprendem no mercado, de modo que não repetem erros cometidos anteriormente. Revisitam seus planos a cada novo conjunto de informações, transmitidos por quaisquer modificações na estrutura econômica que alterem os preços com os quais ele havia criado as expectativas originais. Em resumo, as condições observadas pelo agente fazem com que ele construa expectativas, e a partir delas conceba um plano de ação. Uma vez contrastadas essas expectativas com a realidade, uma nova formulação de expectativas, e consequentemente um plano de ação, entram em funcionamento, mesmo que seja para repetir aquela ideia realizada no momento anterior (KIRZNER, 2012, p. 70).

Como resultado disso tem-se que cada período no mercado é seguido por um outro no qual a informação foi um pouco ampliada. Cada novo aprendizado do agente torna menos provável que ele venha a repetir um erro cometido anteriormente. E é aí que se revela a existência do "processo de mercado" como "inerentemente competitivo", já que cada oportunidade frustrada no período anterior é descartada pelos agentes que a observaram, do mesmo modo que aquelas 
que se mostraram aproveitáveis serão agora disputadas pelos participantes (KIRZNER, 2012, p. 21).

Nesse processo é que se destaca a informação sobre vias de ações não exploradas pelos agentes, originada pela diferença entre aquilo que foi ou não realizado no mercado, abrindo espaço para atividades lucrativas - as oportunidades não exploradas. Com a revisitação dos planos ao longo do tempo, algumas vias de ação vão se destacando para um ou mais indivíduos como oportunidades lucrativas. Kirzner (2012, p. 186) aponta isto como falta de coordenação entre os agentes, coordenação essa que vai se ampliando conforme mais informação é acumulada e, portanto, menos erros vão sendo cometidos. É por meio da ação empresarial, a iniciativa do homem que age na busca da satisfação de uma preferência, que a informação vai ampliando-se individualmente, e daí difunde-se para o restante da economia.

\subsubsection{Ação empresarial}

Seguindo a tradição de Mises (2010), Kirzner (2012, p. 37) adota como ponto de partida da sua explanação o arcabouço teórico da ação humana, em que o indivíduo (o homo agens) age, em qualquer esfera de atividades na sua vida, para remoção de algum desconforto, e escolhe os meios que julga mais adequados para isso. Portanto, age racionalmente. Conquanto essa racionalidade seja subjetiva, ela é dependente das informações e da percepção que o indivíduo tem em relação a elas, disponíveis no instante em que decide seu plano de ação. Partindo desse princípio, o autor segue explicando que sua proposta será de isolar os aspectos da ação humana nas atividades realizadas no mercado, reunindo-os sob o conceito de elementos empresariais, de modo que ação empresarial nada mais seja do que parte da própria ação humana, mas exclusivamente aquela que é realizada no mercado com a interação junto a outros indivíduos.

Essa necessidade de delinear dentro da ação humana um componente unicamente empresarial, que só se manifesta nas relações mercantis do indivíduo e portanto um aspecto exclusivamente teórico e não-observável, advém da contestação da tese, defendida na teoria dos preços de que os agentes econômicos praticam uma "maximização" dos seus interesses durante as transações que realizam. Enquanto a tradição Neoclássica imputa aos agentes econômicos a tarefa de realizar suas decisões com base em cálculos de maximização, de tal modo que a ação dos indivíduos se mostra passiva, uma vez que seus gostos estão dados e aos agentes só cabe o papel de fazer a escolha ótima, a perspectiva kirzneriana vê nessa decisão um papel ativo. Tal atividade implica interpretar subjetivamente as possibilidades de escolha, admitindo a possibilidade de equívocos na interpretação dos melhores meios disponíveis aos fins pretendidos, porque nessa ideia de ação racional os indivíduos escolhem com base em um conjunto limitado de informações 
e expectativas criadas internamente quanto aos desdobramentos das suas possíveis escolhas (KIRZNER, 2012, p. 40).

Como resultado disso, tem-se aberta a possibilidade, estranha à teoria dos preços, de interpretar as mudanças de escolha de um indivíduo como um padrão de decisão, em que suas escolhas interpõem-se num conjunto sucessivo e lógico de seleções realizadas racionalmente, cada uma dependendo da anterior em função das experiências passadas e respectivas expectativas, independentemente de que sejam coerentes quando analisadas individualmente, seja pelo sucesso ou pelo fracasso dos resultados obtidos - já que ambas fornecem novas informações ao agente. Segundo Kirzner, na teoria Neoclássica, essa alternativa é inviável, porque cada decisão considera apenas o grupo de fatores presentes no momento de determinada escolha, e mudanças no comportamento de escolha seriam interpretadas como descontinuidades irracionais, dada a aceitação das premissas iniciais (preferências, tecnologia e recursos), que implicariam sempre uma única via de ação, em um determinado momento, para o agente atingir os resultados almejados, tal que não é possível agrupar decisões divergentes em um padrão de busca deliberada por satisfação (remoção do desconforto) ao longo do tempo (KIRZNER, 2012, p. 41).

Mas esse tratamento de Kirzner ao comportamento empresarial, como pertinente a toda ação humana, não exclui a importância que tem o papel do empresário na teoria econômica, muito pelo contrário. 0 autor $(2012$, p. 72$)$ busca defini-lo como um explorador de oportunidades, em contraponto a visão tradicional de que ele as cria, porque percebe possibilidades de lucro já existentes e as empreende:

[...] 0 empresário é a pessoa que contrata os serviços de meios de produção. Entre esses meios, podem estar pessoas com melhor conhecimento de informações de mercado, mas o próprio fato de que esses detentores de informação contratados não a exploraram eles mesmos mostra que, talvez no seu sentido mais verdadeiro, esse conhecimento é possuído, não por eles, mas por aquele que os está contratando. É este que "sabe" quem contratar, que "sabe" onde encontrar os que dispõem das informações de mercado necessárias para localizar oportunidades de lucro (KIRZNER, 2012, p. 67).

Portanto, a atividade empresarial é apresentada por Kirzner também como "estado de alerta", a capacidade de percepção das possíveis fontes de lucro. Como as oportunidades são geradas pelo resultado conjunto das decisões dos indivíduos, elas têm origem nas ações intencionais e não intencionais. Em qualquer um dos casos, um indivíduo ao agir pode estar criando possibilidades de lucro que ele mesmo não enxerga, que podem ser exploradas por outros empresários. É por isso que essas oportunidades são existentes e não criadas propositadamente: 
[...] uma vez que nos tornamos sensíveis ao estado de alerta dos tomadores de decisões para novos fins e meios potencialmente interessantes, pode ser possível explicar o padrão de mudança nas decisões de determinado indivíduo como resultado final de um processo de aprendizagem gerado pela experiência acumulada das próprias decisões (KIRZNER, 2012, p. 41).

Toda essa teorização sobre o elemento empresarial na ação humana, sobre a atividade empresarial como realização concreta do empresário e sobre seu atributo para perceber essas oportunidades, o estado de alerta, dependem do isolamento teórico, comentado anteriormente, de um fator específico na atividade humana que Kirzner denominou "Empresário Puro". O funcionamento desse arcabouço é dependente da separação dessa característica, que ocorre apenas ao nível teórico, para ilustrar seu funcionamento como mecanismo distintivo da ação empresarial. Tal que, o aprofundamento teórico de Kirzner sobre a atividade empresarial implica um grau maior de abstração. Ele pretende a separação de oportunidades de lucro, assim como das ações empresariais, entre aquelas que são ou não puras. 0 autor propõe que o lucro empresarial puro é unicamente resultante da diferença entre preços de compra e venda de uma mercadoria, nos seus termos:

[...] provém da descoberta de vendedores e compradores de alguma coisa pela qual os últimos pagarão mais que os primeiros pedem. A descoberta de uma oportunidade de lucro significa a descoberta de alguma coisa obtenível em troca de nada (KIRZNER, 2012, p. 51).

Como o objeto pretendido neste artigo é o de comparar Penrose e Kirzner, a consideração da Atividade Empresarial como arcabouço mais amplo já é suficiente. Neste ponto basta apresentar ao leitor que a proposta kirzneriana não acaba na exposição da Atividade Empresarial, esta já traduzida de Mises (2012), antes, há a contribuição original do próprio Kirzner (2012) na definição do elemento empresarial puro. Como é um atributo exclusivamente teórico e sem contraparte na teoria penroseana, sua explicação é deixada para os escritos originais do próprio autor.

\subsubsection{Equilíbrio}

Ocorre que o equilíbrio como aceito na tese kirzneriana também difere daquele adotado na teoria Neoclássica, que o admite como um estado em que cessam todas as mudanças endógenas no sistema econômico pelo maior atendimento possível das satisfações pelos participantes do mercado. Kirzner (2012, p. 22) considera que nessa visão de equilíbrio exclui-se por completo a competição, uma vez que nenhuma possibilidade de ganho possa ser percebida por qualquer 
agente, não haveria incentivo para que algum deles empreendesse uma ação concorrencial. Daí que a própria ideia de competição é inseparável da ideia de mercado, porque uma vez que os indivíduos vão renovando seus planos de ação e buscando atender objetivos distintos, eles não deixam de competir entre si pelos ganhos que vão sendo descobertos, o que consequentemente mantém o mercado "vivo".

É por isso que o erro apontado por Kirzner nos conceitos de competição e mercado resultam da incompreensão do papel do empresário na economia. Ao internalizá-lo na análise como produtores de informações exógenas (inovações em produtos e processos, tais como quis Schumpeter [1911]), acabou por desprezar seu papel concorrencial, aquele que busca continuamente as oportunidades de lucro, que modifica as situações do sistema econômico por meio de ações intencionais e não intencionais, bem como pelos acertos e erros que cometem na tentativa de antecipação aos demais, que interpretam e geram a quantidade de informação que tem disponível (KIRZNER, 2012, p. 71).

Kirzner (2012, p. 71) enfatiza que o resultado principal desse erro é tratar o empresário como desequilibrador na economia, uma vez que suas inovações técnicas promovem a urgência de rearranjo do mercado. 0 autor defende que, ao contrário, as ações empresariais têm função equilibradora, já que vão descartando vias de ações ineficientes e permitindo a sobrevivência daquelas de sucesso, disseminando esses resultados positivos ao conjunto do sistema econômico por intermédio da difusão da informação, diminuindo a ignorância dos indivíduos. 0 autor é claro na afirmação dessa ideia:

\footnotetext{
Deduz-se que o movimento do desequilíbrio rumo ao equilíbrio é, ao mesmo tempo, um movimento do conhecimento imperfeito para o conhecimento perfeito, e da descoordenação para a coordenação. Vimos que o movimento do desequilíbrio para o equilíbrio é, simplesmente, o processo competitivo - empresarial, que é um processo de comunicar informação. [...] Esse processo de aprendizagem, ao mesmo tempo, leva os planos individuais a uma coordenação cada vez maior. A regra é simples e óbvia: a coordenação de informação garante a coordenação de ação (KIRZNER, 2012, p. 188, grifo nosso).
}

Esse entendimento retoma a contribuição de Hayek (1948) sobre o sistema de preços. Kirzner considera que o preço final transmite um total de informação já coordenada no mercado, tal qual uma "informação final" aos agentes. Mas, durante o processo de mercado competitivo, em que os indivíduos concorrem e seguem planos de ações concebidos individualmente, o que se comunica é o desenvolvimento contínuo dos preços, como se a cada instante houvessem preços intermediários ainda não consolidados como preços finais no sistema, no rumo ao preço ou à informação final, que ocorreria unicamente no equilíbrio. 
Portanto, o processo competitivo é caracterizado pelo estágio em que há imperfeição do conhecimento, em que cada indivíduo continua buscando a satisfação dos desejos iniciais e realizam-na no mercado, tendo como consequência direta e indireta o atendimento das necessidades de outros indivíduos. Nesse processo caminha-se para a eliminação das desigualdades de informação, em que o conhecimento vai tornando-se cada vez mais perfeito, em que há gradativamente maior grau de coordenação dos agentes, em um processo de adoção e eliminação de estratégias de ação pelo método de tentativa-e-erro, seja próprio ou de terceiros, já que ambos geram informações que se espalham e ampliam o conhecimento na economia (KIRZNER, 2012, p. 202).

Fica claro que Kirzner (2012, p. 202) defende essas vias de ação tomadas pelos indivíduos como mais ou menos acertadas de acordo com a quantidade e o tipo de informações que eles possuem, individualmente ou em conjunto, relativo ao estágio do desenvolvimento econômico. Com o tempo, novas tecnologias impõem novas técnicas que permitem novas estratégias de ação, viabilizando novas oportunidades de ação empresarial, que tornam o processo cada vez mais intensivo no atendimento das necessidades individuais a custos menores, promovendo uma coordenação cada vez maior.

Desse modo, o autor parece sugerir que qualquer equilíbrio no mercado é uma situação impossível, que existe apenas para determinado instante no tempo dada a quantidade de informações disponível, mas que no momento seguinte será outro, dado o processo de mercado ser dinâmico e transformador dessa quantidade de informações. 0 que seria permanente é a tendência ao equilíbrio, existente pela motivação individual dos agentes de alcançar uma situação melhor, que gera ganhos espraiados, promovendo maior coordenação entre os participantes do sistema econômico. E é aí que é necessário retornar para o ponto inicial da análise, de informação no processo de mercado, visto que a interação de intenções dos agentes tem base no conhecimento subjetivo de cada um deles, que determina a ação empresarial de cada um.

\section{Contrastando com as conclusões de Penrose}

Esta seção tem por objetivo analisar brevemente como as ideias anteriormente identificadas na seção três, que resume as conclusões penroseanas, seriam encaradas na perspectiva kirzneriana, recordando-as: (i) sobre o tamanho ótimo da firma; (ii) sobre a descentralização das atividades da empresa; e (iii) sobre a contradição sobre as imposições artificiais na economia. Pela abordagem austríaca adotada nas concepções de Kirzner (2012), não é difícil perceber que o primeiro ponto seria encarado igualmente pelo autor, enquanto o segundo seria passível de controvérsia, e o terceiro definitivamente estaria fora de questão. 
Quanto ao ponto (i), considerando o caráter subjetivo de sua análise, jamais poderia a teoria afirmar, a priori, um tamanho ótimo para a firma, considerando tanto a incerteza subjacente ao processo de mercado como a ausência de um ponto de equilíbrio alcançado dentro dele, tal que a empresa pode variar de tamanho constantemente ao longo do tempo sem que se possa afirmar que um seja, em absoluto, melhor que o outro. Apenas se poderia investigar se a via de ação escolhida, na tentativa do crescimento, era a mais acertada de acordo com a quantidade de informação que se tinha e a interpretação que lhe foi dada.

Em relação ao ponto (ii), ele pode ser verdadeiro ou falso dentro da teoria kirzneriana. Verdadeiro porque poderia implicar maior eficiência na administração diversificada das empresas, mas também falso porque alguns interesses individuais poderiam estar em permanente conflito dentro da firma, tal que a diversificação acarretaria nos famosos problemas de agência. Assim, não há como apontar o resultado esperado pela assimetria de informação envolvida, a não ser que houvesse alguma garantia de que os ganhos dos agentes econômicos intra-firma estivessem alinhados na busca dos mesmos objetivos. Portanto, não há conclusão sobre essa controvérsia.

Por fim, o ponto (iii) é fora de cogitação pela teoria da competição de Kirzner. Sua proposta teórica reúne a defesa do livre mercado de Mises (2012) com a natureza do conhecimento subjetivo e disperso de Hayek (1948), tendo como resultado uma defesa ferrenha da eficiência do processo de mercado, e como conclusão de que ele não deve sofrer interferência. De modo que, mesmo que as grandes empresas venham a manter as barreiras artificiais no mercado, isto é resultado de processos de decisões anteriores que permitiram às firmas a posse absoluta dos recursos que lhe dão poder de monopólio. Nesse sentido, estaria aberta às concorrentes a procura por bens substitutos na produção que lhes retirasse isso. Do ponto de vista subjetivo, qualquer interferência externa nesse conjunto poderia piorar a situação, pois por mais bem desenhadas que sejam as políticas, e a boa vontade de sua intenção, cabe notar que não se pode afirmar com certeza os resultados não intencionais dessa intervenção, que poderiam acabar por prejudicar as concorrentes ou a economia como um todo. Basta notar que uma pequena firma favorecida com uma política que lhe permita competir no mercado estará, após o seu crescimento, em desfavor no mercado em relação a novos competidores justamente pela política que lhe permitiu chegar lá.

\subsection{Origem das divergências: os conflitos metodológicos}

Esta seção tem por objetivo resumir os principais pontos de convergência e divergência entre as ideias penroseanas e kirznerianas, destacar como isto interfere nas concepções dos dois autores sobre as conclusões resumidas da obra de Penrose 
(2006), e apresentar o foco dessas diferenças como resultado da metodologia aparentemente adotada pela autora.

Como motivos de convergência, destaque é dado: (i) caráter subjetivo da informação/conhecimento; (ii) lucro como motivação central do agente em análise; (iii) defesa da manutenção do caráter competitivo do mercado; (iv) posse dos ativos essenciais como fonte de excedente econômico; (v) ênfase no processo de competição em detrimento à análise de equilíbrio; e (vi) mercado como resultado de ações intencionais e não intencionais, que em Penrose pode ser visto na explicação dos "interstícios".

Já quanto aos pontos de divergência, tem-se, principalmente: (i) agente econômico a ser analisado; (ii) o papel do empresário no ambiente econômico; e (iii) natureza das hipóteses que fundamentam a teoria.

A metodologia utilizada por Kirzner (2012) sustenta-se em duas posições centrais em sua obra: o individualismo e o subjetivismo (BOETTKE; SAUTET, 2015, p. x). Sobre o subjetivismo, Boettke e Sautet (2015, p. ix) afirmam que não há como separá-lo da teoria da ação empresarial do autor, até porque, para os autores, em outro trabalho (2010, p. ix) tal abordagem é um tema que permeia toda a obra dele.

O próprio Kirzner ([1976] 2015) manifestou-se sobre as linhas gerais da metodologia Austríaca, que seriam: (1) o subjetivismo; (2) a ênfase na ação humana propositada - o que denota o individualismo; (3) o descontentamento com a centralidade na posição de equilíbrio; (4) a desconfiança com relação às medições empíricas; e (5) o ceticismo com relação ao empirismo como critério de confirmação teórica. Todos eles compatíveis com sua teoria da Atividade Empresarial (KIRZNER, 2012).

Logo, a busca de Kirzner (2012) por apontar a função empresarial no sistema econômico carrega consigo as posições centrais identificadas em sua metodologia. Ao observar a atividade empresarial, está admitindo o individualismo metodológico, porque sua análise parte da tomada de decisão individual realizada pelo empresário. Já o subjetivismo é visto na admissão de relativizar-se a explicação e os resultados das escolhas dos empresários com base no conjunto de informações disponíveis a eles. Também está presente no entendimento das mudanças decisórias que ocorrem ao longo do tempo com base nas informações que os empresários descobrem no processo de mercado.

Portanto, resta tentar identificar a abordagem metodológica adotada por Penrose (2006) em seu livro, para justificar esses três pontos de divergência com relação a Kirzner (2012). Justifica-se tal procedimento como uma tentativa porque Penrose não aponta uma proposta e/ou autor a ser seguido nesse sentido, e nem explicita um método científico em sua obra. Assim, o que segue é uma sugestão de interpretação para a metodologia da autora com base em passagens do seu livro.

Uma primeira característica da abordagem penroseana é o fato da autora apontar, no prefácio da edição de 1995, que um dos principais pressupostos 
adotados é a importância da história, não enquanto determinista, mas pela passagem dinâmica do tempo que permite o acúmulo de conhecimento na firma propositada (PENROSE, 2006, p. 16 - prefácio da terceira edição, 1995). Aqui, novamente fica evidente a escolha metodológica pela firma como objeto de análise, como se ela fosse dotada de ambições e realizasse escolhas individuais, ignorando os conflitos de interesses internos na empresa.

Causa estranheza essa escolha porque a própria autora (2006, p. 33) reconhece a importância de levar em conta os objetivos de ganho dos seres humanos que estão considerados dentro da firma, apontando a necessidade desses fatores serem levados em conta. Mas o faz somente em contraste com a teoria Neoclássica, permanecendo a adoção da firma como foco teórico de decisões.

Uma segunda característica, dependente da primeira, é que nessa visão da firma opta-se pela exclusão do papel do empresário, uma vez que sua função na empresa é somente a de prestador de serviços, tal como qualquer outro fator de produção empregado, e o mais longe que a autora vai na sua consideração é separar os papéis empresariais dos administrativos (PENROSE, 2006, p. 72). Isto leva à justificativa de que esse papel empresarial será aqui interpretado como gerencial, pois é tão mecânico quanto o papel da firma na teoria Neoclássica, já que busca uma solução por meio de um conjunto dado de informações de mercado, ignorando o papel criativo empresarial.

Esse tópico é de especial interesse pois, de acordo com o que será analisado em Kirzner (2012), pelo "vocabulário austríaco", Penrose estaria tratando como empresarial uma função gerencial. Ao confundir esses termos a autora anula o papel da ação deliberada, que deixa de ser exercida pela firma, uma entidade que ela mesma considera como um conjunto de pessoas escolhidas dentre um todo, mas não aponta nem justifica o que os leva a trabalhar em conjunto e nem mesmo onde começam. Nesse sentido, não se sabe nem onde começa nem onde termina uma empresa ao longo do tempo.

Uma terceira característica é a natureza do conhecimento que fundamenta as hipóteses que sustentam a teoria penroseana. A autora afirma que está adotando como pressupostos apenas aspectos do "mundo real", a fim de evitar muitas abstrações, porque o público objetivado por ela abrangeria mais do que os "economistas profissionais" (PENROSE, 2006, p. 34). Aí recai outra falha na abordagem metodológica proposta, uma vez que a consideração de tais aspectos reais estaria local e temporalmente confinada ao período de observação da autora, bem como a subjetividade da sua interpretação.

Além disso, aponta que a validade de tais afirmações poderia ser constatada com a observação dos "exemplos concretos", como se estes garantissem a validade das suas preposições. Ainda que faça a ressalva de que exemplos confirmatórios são menos importantes do que os que desacreditam a proposta, segue por esse caminho, resguardando-se ao apontar os exemplos apenas como fonte de ilustração 
(PENROSE, 2006, p. 34). Mas, se não há confirmação, para que exemplificar com eventos da vida real? Exemplos abstratos, como utilizados pela autora no papel dos recursos monopolistas, seriam igualmente válidos. Assim, parece que a autora se reserva a admissão de utilizar uma abordagem empirista para a confirmação ou sustentação de suas ideias, embora já tenha se pautado na observação da realidade para escolha das hipóteses a serem administradas em sua teoria.

Conquanto essas características tenham esgotado as divergências entre os autores, cabe ressaltar uma deficiência intrínseca à teoria do crescimento da firma que foi apontada pela própria autora (2006, p. 39): ela só da conta das possibilidades de crescimento concretizadas, só sendo válida ex-post, pois só é capaz de compreender as firmas que conseguiram crescer. Nessa perspectiva, sua validade ex-ante é comprometida porque não pode considerar todos os aspectos envolvidos na incerteza do mercado, de modo que não é capaz de explicar o processo de crescimento das firmas que não cresceram, das que faliram ou que foram adquiridas por concorrentes. Nesse reconhecimento, Penrose defende que segue dessa forma para discutir o tamanho e os limites da taxa de crescimento das empresas, mas fica claro que ao desconsiderar os insucessos está desconsiderando também outros limitadores e causas do decrescimento da firma.

\section{Conclusão}

O objetivo do artigo consistia em uma revisão da teoria do crescimento da firma de Penrose, à luz das contribuições de Kirzner como parte integrante da Escola Austríaca. Partiu-se da hipótese de que Penrose falha ao não adotar um processo metodológico crível, que lhe permitiria ver ou apontar quão específica é a estrutura de sua análise. Constatou-se que tanto ela quanto Kirzner criticam as explicações teóricas neoclássicas a respeito do papel da empresa e do empresário.

0 ponto central da crítica de Kirzner está no fato de que as análises neoclássicas desconsideram o papel empresarial exercido pelos agentes no mercado. Penrose, por sua vez, no que se refere ao equilíbrio na teoria tradicional, aponta que pouco ou nenhum interesse seria dado ao interior da firma, suas estratégias de competição e crescimento. Dessa maneira, a empresa seria tomada apenas como contraparte produtiva dos indivíduos econômicos que também promoveriam o equilíbrio através da busca pela satisfação dos seus interesses, maximizando seus lucros.

Sobre a natureza do conhecimento, os dois autores têm posições divergentes. Kirzner, seguindo a Escola Austríaca, pretende analisar a disseminação do conhecimento por meio dos agentes individuais, que agem deliberadamente, aprendendo por meio do processo de mercado. Por sua vez, Penrose não apresenta proposta metodológica nesse sentido, permitindo-se 
partir de hipóteses elaboradas com base na realidade observada e, com isso, discutir as possibilidades de crescimento da firma.

Já quanto à conceituação da firma, Penrose define-a como uma unidade de planejamento, cujo cerne está em congregar as atividades gerenciais e administrativas. Mostra que seu objetivo último é o lucro que guia as atividades produtivas. Complementar à ideia de empresa vem a de empresário. Nesse caso, Penrose apresenta-o como aquele que exerce um papel gerencial que, no seu entendimento, é apenas diferente do papel administrativo nessa perspectiva de deixar a cargo da firma a função de empreender no mercado. Concepção diferente da defendida por Schumpeter, para quem o empresário era visto como o promotor do crescimento econômico ao gerar inovação tecnológica, em qualquer área das empresas, que permitisse romper com o padrão prevalecente e tornar a firma mais eficiente que as demais, o que resultaria numa revolução do mercado até que todas se adequassem a esse novo padrão, ou fossem eliminadas no processo. Por isso o empresário schumpeteriano é admitido como desequilibrador do sistema econômico, porque suas inovações promovem a descontinuidade do estado de equilíbrio econômico. Diferente de ambos, Kirzner define o empresário como um explorador de oportunidades, em contraponto à visão tradicional de que ele as cria deliberadamente, porque a criação de uma oportunidade de lucro depende da descoberta de sua existência, que só ocorre no momento da exploração dessa oportunidade. Assim, em Kirzner, o empresário age de maneira empresarial ao extinguir um diferencial de preços no sistema econômico, promovendo uma tendência ao equilíbrio na economia.

Outro tema abordado é a forma como as empresas crescem. Para Penrose, o crescimento se dá por diversos motivos, como: i) as vantagens advindas de ser uma empresa maior, em relação às menores, na introdução de novos produtos e/ou tecnologias no mercado; ii) os menores custos possíveis pela diversificação da produção; iii) os ganhos de eficiência produtiva por meio da integração vertical, eliminando fricções entre as etapas do processo produtivo; iv) as vantagens adquiridas pelas firmas mais antigas, já que sua consolidação ao longo do tempo permite experiência no enfrentamento das situações adversas. Kirzner, por sua vez, não se propondo a analisar a empresa, considera apenas o empresário. Tal agente é motivado no sistema econômico na busca por lucros, o que alcança por intermédio do "estado de alerta" para oportunidades inexploradas, que são criadas por ele no momento de sua percepção e aproveitamento.

Há, ainda, pontos de convergência e divergência entre as ideias penroseanas e kirznerianas. Como motivos de convergência, destaque para: i) o caráter subjetivo da informação/conhecimento; ii) o lucro como motivação central do agente em análise; iii) a defesa da manutenção do caráter competitivo do mercado; iv) a posse dos ativos essenciais como fonte de excedente econômico; v) a ênfase no processo de competição em detrimento à análise de equilíbrio; e vi) o mercado como 
resultado de ações intencionais e não intencionais. Em relação aos pontos de divergência, tem-se: i) o agente econômico a ser analisado; ii) o papel do empresário no ambiente econômico; e iii) a natureza das hipóteses que fundamentam a teoria.

Por fim, destaca-se que esta pesquisa, que se debruçou na compreensão de dois autores e suas principais obras a respeito do entendimento da empresa, pode abrir caminho para a análise de outros pensadores e de outras obras seminais que corroboram para o entendimento da firma, do empresário e do ambiente no qual as empresas desenvolvem suas atividades.

\section{Referências}

BAIN, Joe S. Barriers to New Competition. Cambridge: Harvard University Press, 1956. DOI: https://doi.org/10.4159/harvard.9780674188037

BAPTISTA, Margarida A. C. A abordagem neo-schumpeteriana: desdobramentos normativos e implicações para a política industrial. Campinas: UNICAMP - IE, 1997.139 p. Tese (Doutorado) - Instituto de Economia, Universidade Estadual de Campinas, 1997.

BOETTKE, Peter J.; SAUTET, Frédéric E. Introduction to the Liberty Fund edition. In: BOETTKE, P. J.; SAUTET, F. E. (eds.). The Collected Works of Israel M. Kirzner: Austrian Subjectivism and the Emergence of Entrepreneurship Theory, Vol 5. Indianapolis: Liberty Fund, p. ix-xii, 2015.

BOETTKE, Peter J.; SAUTET, Frédéric E. Introduction to the Liberty Fund edition. In: BOETTKE, P. J.; SAUTET, F. E. (eds.). The Collected Works of Israel M. Kirzner: Essays on Capital and Interest, Vol 2. Indianapolis: Liberty Fund, p. ix-xiii, 2010.

CALDWELL, Bruce, J. Hayek's Challenge: An Intellectual Biography of F.A. Hayek. Chicago: The University of Chicago Press, 2004. DOI: https://doi.org/10.7208/chicago/9780226091921.001.0001

HAYEK, Friedrich. A. Individualism and Economic Order. Chicago: The University of Chicago Press, 1948.

KIRZNER, Israel M. Competição e Atividade Empresarial. São Paulo: Instituto Ludwig Von Mises, 2012.

KIRZNER, Israel M. On the method of Austrian Economics. [1976]. In: BOETTKE, P. J.; SAUTET, F. E. (eds.). The Collected Works of Israel M. Kirzner: Austrian Subjectivism and the Emergence of Entrepreneurship Theory, Vol 5. Indianapolis: Liberty Fund, p. ix-xii, 2015. 
MAKOWSKI, Louis. OSTROY, Joseph M. Perfect Competition and the Creativity of the Market. Journal of Economic Literature, vol. XXXIX, p. 479-535, 2001. DOI:

https://doi.org/10.1257/jel.39.2.479

MELO, Luiz M. Modelos Tradicionais de Concorrência. In: KUPFER, David;

HASENCLEVER, Lia. (Orgs). Economia Industrial: fundamentos teóricos e práticos do Brasil. 1ạ edição. Rio de Janeiro: Elsevier, 2002. DOI: https://doi.org/10.1016/B97885-352-6368-8.00001-3

MENGER, Carl. Principles of Economics. New York: New York University Press, 1976.

MISES, Ludwig. Ação Humana. São Paulo: Instituto Ludwig Von Mises, 2010.

PENROSE, Edith. A teoria do crescimento da firma. Campinas: Editora da Unicamp, 2006.

PONDÉ, João L. S. P. S. Coordenação e aprendizado: Elementos para uma teoria das inovações institucionais nas firmas e nos mercados. Campinas: UNICAMP - IE, 1993. 152 p. Dissertação (Mestrado) - Instituto de Economia, Universidade Estadual de Campinas, 1993.

SCHUMPETER, Joseph A. Teoria do Desenvolvimento Econômico: uma investigação sobre lucros, capital, crédito, juro e o ciclo econômico. São Paulo: Abril Cultura, 1997.

SYLOS-LABINI, Paolo. Oligopólio e progresso técnico. São Paulo: Abril Cultural, 1986. 